\title{
Understanding the phenomenon of a real contract: stereotypes, new approaches, and scientific value
}

\author{
Mikhail Fedorovich Kazantsev* \\ Department of law, Institute of Philosophy and Law of the Ural Branch of the Russian Academy of Sciences, Yekaterinburg, Russia
}

\begin{abstract}
The article deals with the definition of a real contract. It is shown that understanding the phenomenon of a real contract is based on the stereotypes: it is defined as an act of transferring a thing in the purchase and sale (tradition). This stereotype does not reflect reality. The transfer of a thing based on the sales contract is not a contract or any other transaction at all. This transfer is an execution of the sales contract. The real contract is a purchase and sale contract. In order to overcome stereotypes in the understanding of a real contract, a new methodological approach based on the doctrine of the subject of civil contractual regulation is required. The basis for classifying civil law contracts is the classification of contracts by the subject of regulation. The real civil contract is a civil contract aimed at regulating proprietary legal relations. Understanding the phenomenon of a real contract has scientific value, since it allows us to identify the legal nature of a real contract, and advances the theory of contract law by classifying contracts by the subject of regulation into obligation, real and real obligation ones.
\end{abstract}

\section{Introduction}

The contract law occupies more than half of all civil legislation rules. Accordingly, in theory and in practice, the problem of contract law prevails. However, with all the huge array of literature on contracts, there are topics that have been understudied by civilists. The latter include the problem of understanding real contracts in civil law.

The phenomenon of a real contract, well known to Russian pre-revolutionary civil law [1] and almost never mentioned in the Soviet civil law literature [2, p. 396], is more and more actively studied by domestic civilists [36]. Literature on real contracts shows that real contracts are defined in line with long-established stereotypes and without proper methodological support.

The purpose of this article is to explain the phenomenon of a real contract on the basis of new methodological approaches.

\section{Stereotypes in understanding the phenomenon of a real contract}

A common understanding of the real contract in modern civil law science has not yet developed, but the trend has emerged. Most often, real contracts include contracts that serve as a direct basis for the emergence, change, termination, transfer of property rights [7, p. 121]. Real contracts are considered to be a type of administrative transactions, which, in addition to real contracts, include cession [8]. Real contracts are [9, p. 528] contracts of sale [10] and real donation contracts [11, p. 119-121; 12]. Some authors deny the existence of real contracts or their scientific and practical significance [13, p. 12-13].

The most famous case of a real contract in literature is the act of transferring a thing during the sale and purchase (tradition). The perception of tradition as a real contract is the most widespread stereotype. However, this stereotype does not reflect reality.

First, the transfer of a thing based on a contract of sale is not a contract or any other transaction at all. This transfer is nothing more than the execution of the sales contract.

To support the contractual (transactional) nature of the transfer of things, it is argued that the transfer is an agreed bilateral expression of will in the proposal of execution and its acceptance [14, p. 126]. It would seem that the seller proposes to accept (offer) the thing, and the buyer, accepting the thing, agrees with the seller's offer (acceptance), and the contract is obvious. This idea of a transfer as a contract is in fact deceptive.

The transfer by the seller and its acceptance by the buyer do not express mutual consent to the transfer of ownership of the thing, since this consent is expressed directly by the contract of sale itself. It is the purchase and sale agreement that expresses the agreed will of the parties to transfer the thing and the transfer of ownership. Why should the seller and the buyer agree on the transfer of the thing and the transfer of ownership, if under the sale and purchase agreement the seller has undertaken to transfer the thing into the ownership of the buyer, and the buyer has undertaken to accept and pay for it?

\footnotetext{
Corresponding author: kazan.m@mail.ru
} 
By making a contract and executing it, the parties express their agreed will. But the direction of these agreed wills is different. The will of the parties aimed at the conclusion of the contract has a regulatory orientation; therefore, this will creates a contract. The will of the parties aimed at the execution of the contract does not create a contract; on the contrary, the performance exhausts the contract.

The transfer of a thing in pursuance of a contract and its receiving cannot be qualified as a contract even in cases where, at the stage of performance of the contract, the parties agree on other or additional parameters of performance. In these cases, they agree on nothing more than changes to the previously concluded executable contract. For instance, if the seller transfers goods in an assortment that does not correspond to the contract of sale, and the buyer agrees to accept them on account of the execution of this contract, then the seller and the buyer thereby conclude an additional agreement to the contract of sale.

The consistent implementation of the idea of "the proposal of performance under a contract and its acceptance form a contract", on which the qualification of the transfer (tradition) as a contract is based, would lead to the need to qualify each act of the accepted performance as a contract and, consequently, to a manifold increase in contracts concluded, overgrowth of continuing contracts whole "bunches" of some "executive contracts". And this is not an exaggeration. Indeed, with this approach, every payment for housing, electricity, utilities, every delivery by the postman of a periodical to the mailbox should be considered as a contract. What is this - bringing the situation to the point of absurdity? Yes, but only as a way of proving that the transfer (tradition) of a thing in pursuance of a sale and purchase agreement is not a contract (transaction), because in the context under consideration, there is no fundamental difference between a supplier transferring a large batch of technological equipment to a buyer and a newspaper delivery by a postal company to a subscriber by a postman.

Therefore, the transfer of a thing is not the completion of a new contract, but the fulfillment of a previously concluded contract of purchase and sale.

Secondly, the basis for the transfer from the seller to the buyer of real rights to the sold thing is the purchase and sale agreement itself, by concluding which the parties regulate their real relations on the transfer of ownership of the thing.

Thirdly, the transfer (tradition) of a thing during the sale and purchase has legal significance for the transfer of ownership of the thing only when this transfer is associated with the transfer of the thing. The transfer of a thing is a legal fact, with which the moment of the transfer of ownership is associated.

The last example clearly illustrates that the transfer does not have the value of the transaction (agreement), which serves as the basis for the transfer of ownership, and the presence of such a value in the purchase and sale agreement. It is quite obvious that if the moment of transfer of ownership is timed to the expiration of a certain period after the conclusion of the contract of sale, then in this case the transfer of the thing does not determine the moment of transfer of ownership, and even less is the basis for the transfer of ownership. In turn, the expiration of a certain period after the conclusion of the sale and purchase agreement, although it determines the moment of transfer of ownership, is not a legal basis (regulator) of the transfer of ownership and a transaction. In this and in other cases, the legal basis (regulator) for the transfer of ownership is the contract of sale. There are no other options.

In other cases, the transfer of a thing is also irrelevant for determining the moment of transfer of ownership in the purchase and sale, for example, when the moment of transfer of ownership is determined by the moment of payment for the goods or the expiration of a period after the conclusion of the contract of sale.

Thus, the sales contract always governs the legal relationship for the transfer of ownership. Moreover, when the moment of transfer of ownership is timed to the moment of concluding an agreement, it is sufficient for the transfer of ownership. In other cases, additional factors are required (e.g., the transfer of things). But the transfer of a thing is not a contract (transaction) that regulates legal relations on the transfer of ownership. This legal relationship is regulated directly by the sales contract. The transfer of a thing is a legal fact with which the law (Article 223 of the Civil Code of the Russian Federation) associates only the moment of transfer of ownership. The transfer therefore acts as a legal fact that does not have regulatory significance, and does not have the status of a transaction.

Thus, the transfer (tradition) of a thing under the contract of sale does not have properties that would qualify it as a real contract. These properties are inherent to the contract of sale, and it is this contract is a real contract (a real contract of obligation).

Unlike the transfer of a thing, the real donation contract can be attributed to real contracts, since the donation contract is the basis for the transfer of ownership of the thing (gift) from the donor to the donee and regulates the legal relationship between them. The perception of only a real donation contract as a real contract is another stereotype that does not reflect the legal nature of a donation contract.

Describing a real donation contract as a real contract, M.I. Braginsky came to the conclusion that "a real contract, in principle, does not imply any binding legal relationship. Its function is limited by the fact that we are talking about a contract-transaction" [15, p. 226].

Indeed, on the basis of a real donation contract, a legal obligation does not arise, including the obligation of the donor to transfer the thing free of charge into the ownership of the donee and the corresponding right of the latter. But another legal relationship arises, namely, the legal relationship for the transfer of ownership of the thing (gift) from the donor to the donee.

The specified legal relationship does not contain rights and obligations. Therefore, it is difficult to recognize it based on the usual ideas about the content of the legal relationship. But, as it has been said many times earlier, the legal relationship may not include rights and obligations. This is exactly the case with legal 
relationship between the donor and the donee, which is expressed in the transition of ownership of the gift from the former to the latter (as well as the previously analyzed legal relationship on the transfer of ownership, based on a sale and purchase agreement or another agreement on the alienation of property).

The consensual contract is also a real contract. The existence of a legal relationship, which implies the obligation (promise) to transfer the thing as a gift and the right corresponding to this obligation, does not exclude the existence of a legal relationship on the transfer of ownership of the thing (gift) from the donor to the donee. When concluding a donation agreement, no matter whether it is real or consensual, the parties decide the issue of ownership of the thing to be donated and, accordingly, through the donation agreement, regulate the property relationship on the transfer of ownership.

\section{New approaches to understanding the phenomenon of a real contract}

To overcome the stereotypes in the understanding the real contract, new approaches are needed. For understanding real contracts, theoretical conclusions about the subject of civil contractual regulation are of methodological importance.

The civil contract is a legal regulator. Regulatory properties of the contract described in [16;17] and investigated in [18]. Civil regulation should be considered as civil contractual regulation. One can talk about the subject of civil contractual regulation, which is covered by the subject of civil regulation. The subject of civil contractual regulation can be any relationship within the subject of civil law regulation, with the exception of relations that are not subject to civil contractual regulation, as well as relations, whose civil contractual regulation is not allowed by law. Property relations are also subject to civil contractual regulation.

The basis for the classification of civil law contracts is the subject of contractual regulation. The real civil contract is a civil contract aimed at regulating proprietary legal relations.

Real civil law contracts include:

1) agreements aimed at regulating relative legal relations between participants in common property (for example, agreements on converting common joint property into common shared ownership, agreements on determining shares in the common shared ownership, agreements on separable improvements to common property, agreements on the division of property in common shared ownership, and separation of a share from it, agreements on the possession, use and disposal of property in common ownership);

2) real contracts of donation;

3) paid contracts aimed at regulating the transfer of ownership of a thing and not providing for the obligations of the parties to transfer the thing into ownership and pay for the thing;

4) agreements on easements that do not provide for the obligation to transfer the right of limited use of property.

\section{The scientific value of understanding the phenomenon of a real contract}

It is important to define the concept of real contract. The scientific value of the phenomenon of a real contract extends beyond the limits of understanding of the concept of a real contract itself.

The discussion about the real contract has overcome the narrow interpretation of a civil law contract. The real contract became a trigger for the surge of scientific interest in civil law in other civil law contracts in addition to contracts of obligation.

An analysis of the real contract in the context of the contractual regulation or the new approach to understanding a real contract serves as an additional confirmation of the possibility of contractual regulation of real legal relations. After all, the recognition that a real contract acts as a direct basis for the transfer of real rights from one person to another means the recognition of the existence of a relationship between these persons, expressed in the transfer of real rights; the proprietary nature of this relationship, since it implies the transfer of proprietary rights and does not contain rights and obligations; the possibility of contractual regulation of relations on the transfer of real rights, since the effect of the contract implying the transfer of real rights is a regulatory effect on the real relations of these persons.

The understanding of a real contract can be developed if the problem of a real contract is viewed through the prism of the subject of contractual regulation. Confirmation of this is the new approach to understanding the real contract.

Moreover, understanding the phenomenon of a real contract through the prism of the subject of contractual regulation reveals the legal nature of a contract and advances the theory of contractual law as a whole.

When classifying contracts by the subject of regulation, both contracts of obligation and real contracts can be distinguished.

One and the same civil law contract may have different legal relations as its subject of regulation. The subject of regulation of the contract of sale is both obligations and property relations. Consequently, the contract of sale is property-binding. The real-obligation contract is a civil contract aimed at regulating both proprietary and contractual legal relations.

The validity of the allocation of real-obligation contracts does not imply the validity of the assertion of the existence of real-obligation legal relations. Such a legal relationship is impossible due to the incompatibility of the properties of property and legal obligations. The aforementioned legal relations cannot form a certain single proprietary legal relation, if only because, firstly, the real legal relation can be (and according to the traditional concept, it can only be) absolute, and the obligatory one is always relative; secondly, the real legal relationship may not contain rights and obligations, and the legal relationship of obligations only consists of them. At the same time, property and legal relations, without merging into a 
single legal relationship, can be closely related and in their totality form complex blocks of legal relations.

Proprietary contracts include:

1) sales and purchase agreements;

2) exchange agreements;

3) lease agreements;

4) consensual donation agreements;

5) agreements on servitude, providing for the obligation to transfer the right of limited use of property.

Proprietary contracts and real contracts can be referred to the contracts with a property element.

\section{Conclusion}

In understanding the phenomenon of a real contract, there are stereotypes according to which it is an act of transferring a thing in the sale and purchase. However, this stereotype does not reflect reality. The transfer of a thing based on the contract of sale is not a contract or any other transaction at all. This transfer is the execution of the sales contract. The real obligation is the purchase and sale contract.

To overcome stereotypes in the understanding of a real contract, a new methodological approach based on the doctrine of the subject of civil contractual regulation is needed. The basis for the classification of civil law contracts is the classification of contracts by the subject of regulation. The proprietary civil contract is a civil contract aimed at regulating proprietary legal relations.

Understanding the phenomenon of a real contract has scientific value, since it reveals the legal nature of a real contract and advances the theory of contract law by classifying contracts by the subject of regulation into obligation, real and real obligation ones.

\section{References}

1. Yu. Gambarov, Property contract, in: Encyclopedic Dictionary Garnet. Ed. $7^{\text {th }}$, vol. 10. Stlb. 12-18 (Moscow, 1912)

2. O.S. Ioffe, Obligations law (Yurid. lit., Moscow, 1975) $880 \mathrm{p}$.

3. V.V. Berdnikov, Property contract in civil law, South Ural legal bulletin, 3, 53-57 (2001)

4. L.Yu. Vasilevskaya, On the specifics of the legal structure of a real contract under German law, Bulletin of the Arbitration Court of the Russian Federation, 5, 119-132; 6, 93-102 (2003)

5. E.Ya. Motovilovker, The relationship between the sales contract and tradition (in search of a real contract), Problems of civil law and process:
Collection of scientific papers (YarSU, Yaroslavl, 2012) Issue 2, pp. 33-49.

6. E.B. Kozlova, Agreements on the establishment of limited property rights as a basis for updating the theory of property contracts, Bulletin of the Russian Legal Academy, 1, 30-33 (2014)

7. L. Ennekcerus, Course of German law. vol. 1, part 2. Introduction and general part (Foreign literature, Moscow, 1950) $484 \mathrm{p}$.

8. V.V. Berdnikov, Administrative transaction as a way to change the property and legal status of a person, Legislation, 2, 16-22; 3, 30-39 (2002)

9. F.K. Savigny, Law of Obligations (Moscow, 1876) XXXVIII, $580 \mathrm{p}$.

10. D.O. Tuzov, On tradition as a real contract in Russian civil law, Bulletin of the Supreme Arbitration Court of the Russian Federation, 8, 5479 (2007)

11. M.I. Braginsky, On the question of the relationship between property and rights of obligation, in: Civil Code of Russia: Problems, theory, practice: Coll. in memory of S.A. Khokhlova (International Center for Financial and Economic Development, Moscow, 1998) pp. 113-130.

12. G.A. Trofimova, The legal essence of a real contract through the prism of the design of a donation contract, Legislation and Economics, 11, 43-47 (2015)

13. S.A. Sinitsyn, The concept of a real contract in German and Russian civil law: controversial aspects, Legislation, 7, 5-13 (2004)

14. B.L. Haskelberg, On the basis and the moment of the transfer of ownership of movable things under an agreement, Jurisprudence, 3, 121-132 (2000)

15. M.I. Braginskiy, V.V. Vitrianskiy, Law of contract: general provisions (Statut, Moscow, 1997) 682 p.

16. N.G. Alexandrov, On the question of the role of the contract in the legal regulation of public relations, Scientific notes, 6, 60-83 (All-Union Institute of Legal Sciences, Moscow: Yurizdat, 1946)

17. L. Raiser, Vertragsfunktion und Vertragsfreiheit, in: Hundert jahre deutsches rechtsleben: Festschrift zum hundertjahrigen bestehen des deutschen juristentages 1860-1960. (Bandi. Verlag C.F. Muller Karlsruhe, 1960) pp. 101-134

18. M.F. Kazantsev, Civil contractual regulation: initial provisions of the concept, Jurisprudence, 2, 90-102 (2003) 